\title{
IMPORTANCE OF MEASURES TAKEN BY LOCAL AUTHORITIES FOR DEVELOPMENT OF ENTREPRENEURSHIP - A CASE STUDY OF RURAL MUNICIPALITIES IN POLAND
}

\author{
Renata Marks-Bielska ${ }^{1}$, associate professor; Magdalena Wojarska, PhD and Izabela \\ Serocka, M.Sc \\ ${ }^{1}$ Department of Economic and Regional Policy, University of Warmia and Mazury in Olsztyn, Poland
}

\begin{abstract}
The research objective has been to identify activities undertaken by authorities of rural municipalities with the aim of creating a friendly economic and social environment to establish and develop business enterprises. The research was chiefly based on an analysis of primary data collected with the help of a questionnaire designed by the authors, at the turn of 2015/2016. The survey was addressed to mayors of all rural municipalities in Poland (1565 administrative units in Poland). Fully and correctly completed surveys were returned by 770 respondents, which corresponded to a return rate equal $49.2 \%$ (the error of answers from the sample obtained was $3 \%$ ). The research objective was achieved by verifying the hypothesis assuming that authorities from rural municipalities where the increase in the number of enterprises between 2009 and 2018 was the highest were more active creating proper conditions for starting and conducting business. Our analysis of the collected empirical material provided evidence that confirmed the above assumption. The study shows that the authorities of municipalities where there was a high rise in the number of business companies between 2009 and 2018 much more often entered into collaboration with other subjects in order to create an optimal environment for conducting business, were more willing to take measures to increase the participation of entrepreneurs in the creation of suitable conditions for the development of business, and formed more positive assessment of the achieved outcomes.
\end{abstract}

Key words: entrepreneurship, local development, municipality.

JEL code: R10.

\section{Introduction}

Entrepreneurship is a multi-dimensional phenomenon, shaped by social and economic conditions. Entrepreneurship can be treated as an attitude or as a process. Being an attitude, entrepreneurship corresponds to a trait in human nature, and stands for the readiness to face new challenges, to improve the existing components of the human environment, and to take an active and creative stance towards one's surroundings. In turn, entrepreneurship understood as a process means the creation and development of a business entity (enterprise) (Babuchowska K., Marks-Bielska R., 2013; Feher A. et al., 2014). Rural entrepreneurship is acknowledged to be an important contributor to the economic development of a country (Holcombe R., G., 1998; Ahmad et al., 2011; Feher A. et al., 2014).

Business activity in rural areas in its fundamental aspects occurs in the same forms as in towns. However, the circumstances in which it is conducted are different, often more difficult than in urban centres. The experience gained by many countries implicates that local authorities can play a very important role in the stimulation of entrepreneurship. Each municipality possesses specific economic potential and a certain number of enterprising persons who can activate this potential if offered suitable conditions. To a large extent, this depends on local authorities. It is important that they act efficiently, so as to employ the local resources and create a good climate for conducting business in the administrative unit they govern. The range of problems local governments are faced with is enormous, but there are more and more municipalities able to overcome difficulties (Klodzinski M., 2015).

Actions undertaken by local governments can become a significant determinant of the level of entrepreneurial activity. Decisions which they make can stimulate the establishment of new 
companies. Municipal authorities can directly regulate operations conducted by business entities on the local market (for example, by passing resolutions or decisions, by accepting spatial management studies and plans), and they can actively participate in business (e.g. by conducting economic activity, making investments or selling own property). The indirect impact can consist of forming the environment in which businesses are conducted (e.g. tax rates, contracts, agreements).

The research completed by W. Karaszewski et al. (2016) in four provinces in Poland, among representatives of companies with a share of foreign capital and local governments, suggests that there is a constant need for local authorities to undertake more vigorous actions in order to improve the conditions for conducting business. It is important to notice and to come forward to meet the needs of existing and potential investors, willing to localise and conduct business companies in a given municipality.

For local governments to be able to influence the social and economic development of their local communities, they need to be equipped with proper instruments. These tools should be adjusted to two types of tasks. First, they should enable local authorities to identify the problems appearing in the territory of their administrative units, to analyse internal and external development conditions, and to programme the directions and methods to carry out specific operations. Secondly, the local governments need tools to implement the decisions and programmes they have prepared, through the accomplishment of their strategic goals and inclusion of social and economic subjects in their implementation (Potoczek A., 2012; Marks-Bielska R., 2017).

An approach among economists to determinants of local development and their role in the course of processes occurring in territorial units has been evolving. More and more attention is being paid to the increasing role of internal conditions. Views over what development factors are universal begin to converge. These factors are classified, for example, according to needs of residents and economic entities, resources and assets of a local environment, development and management of infrastructure, economic, technical, human resources and scientific potential, cultural and industrial traditions, activity of the local community, as well as institutional resources. Factors which exert influence on present and future possibilities of the development in a given area can be divided according to various criteria. Considering how they affect development, positive and negative factors can be distinguished. When taking into account possible localisation of companies, factors fall into 'hard' and 'soft' ones. Finally, the origin of factors can be considered giving rise to a division into external (exogenous) and internal (endogenous) circumstances.

Being able to correctly identify the economic functions of a given area, its identity and efficiency in a decision-making process will help us achieve goals established in development processes. In the formation of rural development processes, it is believed that special attention ought to be paid to local resources; another recommendation is to involve local residents (including entrepreneurs) in the process of developing their municipality. Such an approach can reinforce the factors that affect the level of competitiveness of local government units, mostly supporting entrepreneurship, creating a positive image, making the localisation of new businesses an attractive option, creating a good atmosphere for investment projects, enhancing the human capital, promoting natural values and tourism, supporting investments which serve to diversify conducted businesses, as well as building a system of institutions which respond properly to the functions they should perform.

This area calls for continuous research because the available data describing the local governments in Poland prove that these institutions still do not perform their pro-development roles satisfactorily. One immediate cause is the scale and type of transfers from the state's central 
institutions. Changes which are desired would limit the state's interference with the sphere of local economy. This is manifested by limiting the role of the state as the owner of production resources, employer and investor. The indirect influence of the state on local development processes is gradually shifted towards having an indirect influence on decisions of local governments.

The objective of this study has been to identify the measures taken by authorities of rural municipalities in order to create a friendly economic and social climate for the establishment and development of business enterprises. The research consisted mainly of an analysis of primary data gathered with a questionnaire designed by the authors and mailed to potential respondents in 2015/2016. The respondents were mayors (wójt) of all rural municipalities (gmina) in Poland (1565 units constituting the third-tier local governments, i.e. the lowest level in Poland's administrative division). In total, 770 respondents returned fully and correctly completed questionnaires, which corresponded to the return rate of $49.2 \%$ (an error of answers from the sample thus obtained equalled $3 \%$ ). A chi-square test was applied to verify whether the spatial distribution of municipalities in the achieved sample (relative to the highest administrative division into provinces) was significantly different from the distribution in the whole population. The chi ${ }^{2}$ statistics reached a value of 7.25 ( $p=0.950)$, which proved the lack of statistically significant differences between the observed distribution (present in the sample) and the expected distribution (present in the population).

The research aim was attained by verifying the hypothesis stating that authorities of rural municipalities in which the highest increase in the number of business entities between 2009 and 2018 was noted would demonstrate higher activity in the field of creating suitable conditions for starting and conducting business. The indicator $\Delta \mathrm{E}_{\mathrm{i}}$ (an increase in the number of companies in a municipality between 2009 and 2018) served to identify the above group of municipalities, while the process of separation into several groups proceeded through two stages. First, the so-called outstanding cases (i.e. satisfying the condition $\mathrm{x}_{\mathrm{ods}}<2.5 \mathrm{Q}_{1}-1.5 \mathrm{Q}_{3}$ and $\left.\mathrm{x}_{\mathrm{ods}}>2.5 \mathrm{Q}_{3}-1.5 \mathrm{Q}_{1}\right)^{1}$ were excluded from the group, as these were considered to represent groups with either a very high or very low intensity of the analysed trait; afterwards, the remaining municipalities were divided into three classes, according to the determined range $(R)$ and value of the division parameter $\left(k^{2}\right)$. Consequently, the group of 770 municipalities was divided into four separate sets, composed of different number of units, and characterised by different intensity of the indicator $\Delta \mathrm{E}_{\mathrm{i}}$; group I municipalities with extremely high (compared to the whole sample) values of $\Delta \mathrm{E}_{\mathrm{i}}$; group II municipalities with high values of $\Delta \mathrm{E}_{\mathrm{i}}$; group III - with medium values of $\Delta \mathrm{E}_{\mathrm{i}}$; and group IV - with the lowest values of $\Delta \mathrm{E}_{\mathrm{i}}$.

\section{Research results and discussion}

The analysed sample of rural municipalities showed differences in terms of an increase in the number of business enterprises between 2008 and 2018. Nearly half (48.7\%) fell into the group with the lowest values of $\Delta \mathrm{E}_{\mathrm{i}}$, and in 25 of these the difference between the base and the final year was negative. The second most numerous group was composed of municipalities with moderate (i.e. 115 entities on average) increase in the number of business companies (33.6\%). The remaining municipalities presented either a high or a low value of the analysed indicator, and their share in the total sample was $8.7 \%$ and $9.0 \%$, respectively. The basic statistics describing particular groups of

\footnotetext{
${ }^{1} \mathrm{Q}_{1}$ and $\mathrm{Q}_{3}$ stand for the first and third quatrile(https://www.statystyka-zadania.pl/obserwacje-nietypoweodstajace/, access: 9.11.2018). 2 The division parameter $k$ was determined according to the equation: $\mathrm{k}=\mathrm{R} / \mathrm{w}$, where $w$ is the number of groups (Kukuła K., 2015).
} 
municipalities distinguished with respect to a rise in the number of companies between 2009 and 2018 are set in Table 1.

Table 1

\section{Descriptive statistics concerning the increase in the number of companies between 2009 and 2018, according to the distinguished groups}

\begin{tabular}{|l|c|c|c|c|c|c|c|c|}
\hline Specification & $\mathbf{N}$ & $\overline{\boldsymbol{x}}$ & $\min$ & $\max$ & $\mathbf{S D}$ & $\mathbf{V}$ & $\mathbf{S}$ & $\mathbf{K}$ \\
\hline Group I & 69 & 550.19 & 305 & 2095 & 310.74 & 56.48 & 2.65 & 8.99 \\
\hline Group II & 67 & 228.51 & 183 & 290 & 34.30 & 15.01 & 0.41 & -1.21 \\
\hline Group III & 259 & 115.22 & 76 & 181 & 29.58 & 25.68 & 0.50 & -0.90 \\
\hline Group IV & 375 & 39.06 & -112 & 75 & 24.43 & 62.55 & -1.00 & 3.03 \\
\hline
\end{tabular}

Note: $N$ - number of units in the group, $\bar{x}$ - mean; min - minimum value; max - maximum value; SD - standard deviation; $V$ - variability coefficient; $S$ - skewness coefficient; $K$ - coefficient of kurtosis

Source: the authors' calculations based on data from the Local Data Bank

Regardless of which group their municipality was classified into, according to this research, most respondents (92.9\%) declared supporting entrepreneurship actively, both by creating conditions conducive to setting up new businesses and by helping existing companies to conduct and develop their business activity. The support given to entrepreneurs willing to start business consisted mostly of a pro-active approach of officials and local communities (19.8\% of total answers), and it was more often observed among municipalities in groups I (where this response was selected by $75.4 \%$ of respondents) and II (88.1\%) than in groups III (71.0\%) and IV (72.3\%). Other popular instruments included: assistance in finding land parcels or premises for locating a company (13.6\% of total answers), and improved technical infrastructure in the municipality (12.9\%). Among the municipalities with a more intensive rise in the number of companies (groups I and II), the second most frequent reply referred to the assistance in finding some land or premises (this option was indicated by $58.0 \%$ and $56.7 \%$ of the respondents, respectively), while the third most often selected answer was the improved technical infrastructure (46.4 \% - group I, $55.2 \%$ - group II). Among the municipalities with the lower values of $\Delta \mathrm{E}_{\mathrm{i}}$, the order in which these instruments were indicated was reverse - improvement of infrastructure was indicated by $50.2 \%$ of the respondents in group III and $50.1 \%$ in group IV (second place), while assistance in finding a land parcel or premises to set up a company was chosen by $45.2 \%$ of the respondents in group III and $46.4 \%$ in group IV (third place). A similar set of instruments was used by local authorities to support existing companies. Also here, the highest percentage of indications (20.2\%) was gained by the friendly approach of officials and local communities to entrepreneurs, with the betterment of overall infrastructure being the second most popular response (15.0\%). Differences which appeared between the groups concerned the order of actions, which was implied by the frequency of specific indications. Respondents from the municipalities where the number of companies increased between the years 2009 and 2018 the highest (group I) most often pointed to the development of technical infrastructure as a tool of support to operating companies $(59.4 \%)$, while the second most frequent answer was the friendly approach of the authorities and local communities (55.1\%). In turn, the respondents representing municipalities with the smallest increase in the number of companies over the analysed period most often pointed to the modernisation of technical infrastructure, followed by the friendly attitude of the administration and local population (55.1\%). Finally, the respondents from the municipalities where the number of companies either increased the least or even decreased in the analysed decade concentrated first on the attitude of officials and residents (58.9\%) and next on technical infrastructure (40.8\%). 
Creating a climate conducive toentrepreneurial activity does not need to be the responsibility of local authorities alone. In search of a synergistic effect, they can undertake actions in collaboration with other institutions located in or outside their municipality, and engage entrepreneurs in efforts to shape conditions favourable to the growth of business.

This research shows that the local councils in most municipalities collaborated with other entities, although unfortunately such collaboration was not very common (tab. 2).

Table 2

Does your municipality collaborate with other institutions in order to create optimal conditions for conducting business? Structure of responses ( $\%)$

\begin{tabular}{|l|c|c|c|c|}
\hline Specification & No & $\begin{array}{c}\text { Yes, but we rarely } \\
\text { collaborate with } \\
\text { others }\end{array}$ & $\begin{array}{c}\text { Yes, there are a few } \\
\text { institutions with } \\
\text { which we collaborate } \\
\text { regularly }\end{array}$ & $\begin{array}{c}\text { Yes, we have constant } \\
\text { collaboration with a } \\
\text { wide range of } \\
\text { institutions }\end{array}$ \\
\hline Group I & 21.2 & 48.5 & 24.2 & 6.1 \\
\hline Group II & 17.9 & 38.8 & 34.3 & 9.0 \\
\hline Group III & 26.6 & 45.2 & 23.9 & 4.2 \\
\hline Group IV & 35.8 & 41.2 & 21.4 & 1.6 \\
\hline
\end{tabular}

Source: the authors' calculations based on questionnaire survey

Among the institutions engaged by local authorities in the process of creating optimal conditions for conducting business, three were most often indicated, i.e. the Starost's Office (the second-tier local government in Poland; starostwo powiatowe) (20.3\% of total answers), the Marshal's Office (the first-tier local government; Urząd Marszałkowski) (17.5\%) and other municipalities in Poland $(12.2 \%)$. Similar networks of cooperation have been built by local governments in all groups of municipalities distinguished with respect to the value of $\Delta \mathrm{E}_{\mathrm{i}}$, and differences which appeared among them concerned only the frequency of indications. Respondents from groups I and II chose the Starost's Office and other municipalities much more often than those from groups III and IV. The percentages of indications for the former were: $56.5 \%$ and $61.2 \%$ (groups I and II), and $48.6 \%$ and $49.9 \%$ (groups III and IV), while collaboration with other municipalities was chosen by $40.6 \%$ and $46.3 \%$ (groups I and II) and $30.1 \%$ and $26.4 \%$ (groups III and IV). The Marshal's Office was most often indicated by municipalities in the group with a high rise in the value of $\Delta \mathrm{E}_{\mathrm{i}}$ (group II) $(59.7 \%)$, and least frequently in the set of municipalities with a moderate increase in $\Delta \mathrm{E}_{\mathrm{i}}(40.9 \%)$.

Among the activities aiming to create optimal conditions for entrepreneurial activity which the local authorities undertook in collaboration with others, the following were indicated most often: promotion and exchange of information ( $22.4 \%$ of total answers), organisation of cultural and sports events $(20.4 \%)$, implementation of projects with EU funding $(18.5 \%)$, investments into technical/social infrastructure $(17.2 \%)$ and municipal services $(11.2 \%)$. These activities were indicated in the same order (although with some differences in the frequency of indications) in all groups except the first one (Tab. 3).

As mentioned before, activities directed at the creation of a suitable climate for the development of business in a municipality should involve local entrepreneurs as well. An advantage of the inclusive approach is that undertaken activities can be adjusted to specific needs of direct recipients. Unfortunately, the survey showed that nearly $1 / 4$ of the local governments in municipalities did not take advantage of such a solution. Moreover, the percentage of municipalities which did not collaborate with business companies in this capacity was higher in the groups with lower values of the indicator $\Delta \mathrm{E}_{\mathrm{i}}$ (Tab. 4). 
Tasks performed in collaboration with others to create optimal conditions for conducting business in a municipality (in \%)

\begin{tabular}{|l|c|c|c|c|c|c|c|}
\hline \multicolumn{2}{|c|}{ Group I } & \multicolumn{2}{c|}{ Group II } & \multicolumn{2}{c|}{ Group III } & \multicolumn{2}{c|}{ Group IV } \\
\hline Task & $\% *$ & task & $\% *$ & task & $\% *$ & \multicolumn{2}{c|}{ task } \\
\hline $\begin{array}{l}\text { Promotion and } \\
\text { exchange of } \\
\text { information }\end{array}$ & 59.4 & $\begin{array}{c}\text { Promotion and } \\
\text { exchange of } \\
\text { information }\end{array}$ & 64.2 & $\begin{array}{c}\text { Promotion and } \\
\text { exchange of } \\
\text { information }\end{array}$ & $\begin{array}{c}52 . \\
1\end{array}$ & $\begin{array}{c}\text { Promotion and } \\
\text { exchange of } \\
\text { information }\end{array}$ & 44.8 \\
\hline $\begin{array}{l}\text { Infrastructural } \\
\text { investments }\end{array}$ & 50.7 & $\begin{array}{c}\text { Organisation of } \\
\text { events }\end{array}$ & 61.2 & $\begin{array}{c}\text { Organisation of } \\
\text { events }\end{array}$ & $\begin{array}{c}44 . \\
0\end{array}$ & $\begin{array}{c}\text { Organisation of } \\
\text { events }\end{array}$ & 43.2 \\
\hline $\begin{array}{l}\text { Organisation of } \\
\text { events }\end{array}$ & 50.7 & $\begin{array}{c}\text { Implementation } \\
\text { of EU projects }\end{array}$ & 53.7 & $\begin{array}{c}\text { Implementation } \\
\text { of EU projects }\end{array}$ & $\begin{array}{c}41 . \\
7\end{array}$ & $\begin{array}{c}\text { Implementation } \\
\text { of EU projects }\end{array}$ & 39.2 \\
\hline $\begin{array}{l}\text { Provision of } \\
\text { municipal } \\
\text { services }\end{array}$ & 43.5 & $\begin{array}{c}\text { Infrastructural } \\
\text { investments }\end{array}$ & 49.3 & $\begin{array}{c}\text { Infrastructural } \\
\text { investments }\end{array}$ & $\begin{array}{c}39 . \\
8\end{array}$ & $\begin{array}{c}\text { Infrastructural } \\
\text { investments }\end{array}$ & 33.6 \\
\hline $\begin{array}{l}\text { Implementatio } \\
\text { n of EU projects }\end{array}$ & 42.0 & $\begin{array}{c}\text { Organisation of } \\
\text { events }\end{array}$ & 32.8 & $\begin{array}{c}\text { Organisation of } \\
\text { events }\end{array}$ & $\begin{array}{c}22 . \\
4\end{array}$ & $\begin{array}{c}\text { Organisation of } \\
\text { events }\end{array}$ & 22.4 \\
\hline
\end{tabular}

* - percent derived from the number of indications relative the number of units in the set Source: the authors' calculations based on the questionnaire survey

\section{Does the municipality undertake activities to increase the participation of entrepreneurs in creating friendly environment for the development of business? Structure of answers (in \%).}

\begin{tabular}{|l|c|c|c|c|}
\hline Specification & No & A & B & C \\
\hline Group I & 12.9 & 81.4 & 5.7 & 0.0 \\
\hline Group II & 15.3 & 73.6 & 6.9 & 4.2 \\
\hline Group III & 24.5 & 72.0 & 3.4 & 0.0 \\
\hline Group IV & 27.7 & 70.5 & 1.9 & 0.0 \\
\hline
\end{tabular}

A-yes, we make efforts to find out opinions of entrepreneurs and inform them about the most important activities undertaken in the municipality; $\boldsymbol{B}$ - yes, our collaboration with entrepreneurs is based on their regular, planned participation in tasks undertaken together with the municipality; $\boldsymbol{C}$ - yes, we have developed and implemented mechanisms and forms of collaboration with entrepreneurs as a formal group of advisors, which leads to their active, planned and regular participation in most tasks undertaken together with the municipality

Source: the authors' calculations based on the questionnaire survey

In the range of activities performed by local authorities with the aim of increasing the participation of entrepreneurs in the creation of friendly environment for developing business, the following came to the fore: inviting entrepreneurs to participate in sessions of the local council (23.9\% of the total indications), exchange of information on the needs of the local labour market (20.3\%), encouraging entrepreneurs to collaborate in economic and social projects (19.3\%), as well as meetings of councillors and municipal officials to discuss problems encountered by entrepreneurs (17.9 \%).Our analysis of the responses according to the groups of municipalities showed a large diversity in the selected activities in all the groups, except groups III and IV, where the preferences were nearly identical, although in group IV the most frequently indicated activity was to invite entrepreneurs to sessions of the local council (41.9\%) Tab. 5).

The research was concluded by forming a subjective assessment of the activities by local authorities, performed both individually and in collaboration with other institutions or with entrepreneurs. ${ }^{1}$ In each of the three cases (1. individual undertakings, 2 . implemented in collaboration, and 3. involving entrepreneurs), most respondents were of the opinion that the

${ }^{1}$ Respondents assessed the effectiveness of activities on a four-point scale of preferences, where: certainly yes $=3$ points, yes $=2$ points, no $=1$ point, certainly no $=0$ points. The points served to build the indicator $\mathrm{W}\left(\mathrm{W}=\left(\sum \mathrm{n}_{\mathrm{i}} \mathrm{W}_{\mathrm{i}}\right) / \mathrm{kN}\right.$, where: $i$-index of assessment, $n_{i}$-number of indications of a given factor on the $i^{\text {th }}$ place; $k$-maximum assessment on a 0 to $k$ scale; $N$-number of respondents who answered the question; $W_{i-}$ assessment corresponding to the place of factor $i$ ) informing what share of the maximum number of points which could be scored the respondents assigned to a given answer (Karaszewski W., Sudoł S., 1997). 
measures they took contributed to the creation of optimal conditions for conducting entrepreneurial activity. The highest $(\mathrm{W}=0.59)$ effectiveness was assigned to activities implemented by the local governments individually, and this evaluation emerged from both the total analysis and separated into the four groups of municipalities. Moreover, in each of the three areas of activities performed by local authorities, the value of $\mathrm{W}$ index was seen to decrease parallel to the decreasing value of $\Delta \mathrm{E}_{\mathrm{i}}$. This means that respondents from the municipalities where the increase in the number of economic entities between 2009 and 2018 was high or very high assessed the achieved effects better than respondents from the municipalities classified to group IV.

Table 5

Activities undertaken by local authorities in order to increase the participation of entrepreneurs in the creation of friendly environment for the development of business (in \%).

\begin{tabular}{|c|c|c|c|c|c|c|c|}
\hline \multicolumn{2}{|l|}{ Group I } & \multicolumn{2}{|c|}{ Group II } & \multicolumn{2}{|c|}{ Group III } & \multicolumn{2}{|c|}{ Group IV } \\
\hline Task & $\% *$ & task & $\% *$ & task & $\% *$ & task & $\% *$ \\
\hline $\begin{array}{l}\text { Meetings with } \\
\text { councillors and } \\
\text { municipal officials }\end{array}$ & 39.1 & $\begin{array}{l}\text { Collaboration in } \\
\text { social and } \\
\text { economic } \\
\text { projects }\end{array}$ & 52.2 & $\begin{array}{l}\text { Invitations to } \\
\text { sessions of the } \\
\text { local council }\end{array}$ & 37.5 & $\begin{array}{l}\text { Invitations to } \\
\text { sessions of the } \\
\text { local council }\end{array}$ & 41.9 \\
\hline $\begin{array}{l}\text { Invitations to } \\
\text { sessions of the } \\
\text { local council }\end{array}$ & 36.2 & $\begin{array}{l}\text { Invitations to } \\
\text { sessions of the } \\
\text { local council }\end{array}$ & 49.3 & $\begin{array}{l}\text { Exchange of } \\
\text { information } \\
\text { about labour } \\
\text { market }\end{array}$ & 35.5 & $\begin{array}{l}\text { Exchange of } \\
\text { information } \\
\text { about labour } \\
\text { market }\end{array}$ & 32.0 \\
\hline $\begin{array}{l}\text { Exchange of } \\
\text { information about } \\
\text { labour market }\end{array}$ & 36.2 & $\begin{array}{l}\text { Meetings with } \\
\text { councillors and } \\
\text { municipal } \\
\text { officials }\end{array}$ & 43.3 & $\begin{array}{l}\text { Collaboration in } \\
\text { social and } \\
\text { economic } \\
\text { projects }\end{array}$ & 35.1 & $\begin{array}{l}\text { Collaboration in } \\
\text { social and } \\
\text { economic } \\
\text { projects }\end{array}$ & 28.0 \\
\hline $\begin{array}{l}\text { Collaboration in } \\
\text { social and } \\
\text { economic } \\
\text { projects }\end{array}$ & 30.4 & $\begin{array}{l}\text { Exchange of } \\
\text { information } \\
\text { about labour } \\
\text { market }\end{array}$ & 41.8 & $\begin{array}{l}\text { Meetings with } \\
\text { councillors and } \\
\text { municipal } \\
\text { officials } \\
\end{array}$ & 31.3 & $\begin{array}{l}\text { Meetings with } \\
\text { councillors and } \\
\text { municipal } \\
\text { officials } \\
\end{array}$ & 25.9 \\
\hline
\end{tabular}

- percent derived from the number of indications relative to the total number of units in the set Source: the authors' calculations based on the questionnaire survey

\section{Conclusions}

The social and economic environment as well as the spatial circumstances specific to rural areas are different from these which prevail in urban areas. The rural setting is in many aspects much more challenging for conducting and developing business activity.

Municipal authorities which particularly care about the development of local entrepreneurship are open to all economic initiatives, provide friendly climate and professional service to investors, and support the entrepreneurs who conduct their business in the municipality. The policy of the local authorities regarding the acquisition of investors takes into consideration these elements which their municipality comprises (either natural assets or specific solutions that have been implemented) as well as such components that can be created or improved (e.g. infrastructure, taxation policy, quality and efficiency of customer service in offices, cooperation between the authorities and investors).

Entrepreneurship can lead to an enhanced quality of life, and it can help local residents to satisfy their expectations and achieve their aspirations more completely. To a large extent, the development of entrepreneurship ensures the wealth of a local community. And as local inhabitants increase their wealth, the local governments find it easier to implement the tasks they are delegated with. Taking care of local entrepreneurship and creating suitable conditions for the development of economic activity are examples of particularly significant challenges that local authorities are expected to respond to. 
This research was directed towards verifying the hypothesis assuming that local authorities in the rural municipalities where between the years 2009 and 2018 the increase in the number of business companies was the highest demonstrated higher activity in the scope of creating favourable conditions for starting and conducting business. Our analysis of the collected empirical material provided evidence which confirmed the assumed hypothesis. This was particularly evident when reviewing responses to the question about collaboration with other subjects and the one concerning increased participation of entrepreneurs in the creation of a proper climate for developing business. In both cases, the percentage of answers 'the municipality does not undertake such activities' increased considerably as the value of the index $\Delta E_{i}$ decreased. A similar finding emerged from our analysis of the self-assessment by local authorities of effects of undertaken activities, where a decreasing number of businesses between 2009 and 2018 was accompanied by a lower value of the index W.

\section{Bibliography}

1. Ahmad, A.R., Wan, Y., Wan, F., Md Noor, H., Ramin, A.K. (2011). Preliminary Study of Rural Entrepreneurship Development Program in Malaysia. International conference on management (ICM 2011) Proceeding, pp.537-545.

2. Babuchowska, K., Marks-Bielska, R. (2013). The Growth of Rural Entrepreneurship in the Context of the Implementation of the Rural Development Programme in 2007-2013. [In:] Rural Development 2013: Innovations and Sustainability. The Sixth International Scientific Conference. Aleksandras Stuglinskis University, Lithuania, 28-29th November, 2013, Vol. 6, Book 1, pp. 493-498.

3. Feher, A., Gosa, V., Hurmuzache, T., Raicov M. (2014). The Development of Rural Entrepreneurship in Romania. Economic Sciences for Rural Development 2014, Latvia University of Agriculture, Jelgava (International Scientific Conference Proceedings, 24-25 April 2014) (vol. 3(1), pp. 144-149.

4. Holcombe, R.G., (1998). Entrepreneurship and Economic Growth. Quarterly Journal of Austrian Economics $1(2)$, pp. 46-62.

5. Karaszewski, W. 2016 (ed.).Bezposrednie inwestycje zagraniczne w wybranych wojewodztwach Polski analiza porownawcza (Foreign Direct Investment in Selected Polish Voivodships - Comparative Analysis).Wyd. UMK, Toruń.

6. Karaszewski W., Sudol S. (1997). Empirical Research on the Process of Transformation of Polish Companies in the Period of 1990-1995. Wyd. UMK, Toruń.

7. Klodzinski, M. (2015). Zagrozenia i szanse stojące przed rozwojem sektora przedsiebiorczosci wiejskiej (Threats and Opportunities Facing the Development of the Rural Entrepreneurship). Wies i Rolnictwo. No 2(167). pp. 125-138.

8. Kukula, K. (2015). Struktura oraz dynamika produkcji energii odnawialnej w państwach UE (Structure and Dynamics of Renewable Energy Production in the EU Countries). Europa Regionum. Vol. 23, pp. 173-184 (DOI: $10.18276 /$ er.2015.23-14).

9. Marks-Bielska, R. 2017. The Role of Local Authorities in Creating Conditions for the Development of Economic Activities: a Case Study of Rural Municipalities in Poland. Proceedings of the 8 th International Scientific Conference Rural Development 2017. Edited by prof. Asta Raupelienè.

10. Potoczek, A. (2012). Interwencjonizm samorzadowy w praktyce dzialania władz publicznych (na przykladzie Funduszu Wsparcia w woj. kujawsko-pomorskim) (Interventional Self-government in the Practice of Public Authorities (an Example of the Support Fund in Kujawsko-pomorskie Voivodeship)). Studia Lubuskie. Vol. VIII, pp. 245-265. 